\title{
KINETICS OF HIGH-LEVEL OF B-GLUCOSIDASE PRODUCTION BY A 2-DEOXYGLUCOSE- RESISTANT MUTANT OF HUMICOLA LANUGINOSA IN SUBMERGED FERMENTATION
}

\author{
Syed Ali Imran Bokhari, Farooq Latif, Muhammad Ibrahim Rajoka* \\ National Institute for Biotechnology and Genetic Engineering P.O. Box 577, Faisalabad, Pakistan
}

Submitted: November 13, 2007; Returned to authors for corrections: February 05, 2008; Approved: November 10, 2008.

\begin{abstract}
A 2-deoxyglucose-resistant mutant (M7) of Humicola lanuginosa was obtained by exposing conidia to $\gamma$ rays and permitting expression in broth containing 0.6\% 2-deoxyglucose (DG) and cellobiose (1\%) before plating on DG esculin-ferric ammonium citrate agar medium from which colonies showing faster and bigger blackening zones were selected. Kinetic parameters for enhanced B-glucosidase (BGL) synthesis by M7 were achieved when corncobs acted as the carbon source. The combination between corncobs and corn steep liquor was the best to support higher values of all product formation kinetic parameters. Effect of temperature on the kinetic and thermodynamic attributes of BGL production equilibrium in the wild organism and M7 was studied using batch process at eight different temperatures in shake-flask studies. The best performance was found at $45^{\circ} \mathrm{C}$ and $20 \mathrm{~g} \mathrm{~L}^{-1}$ corncobs in $64 \mathrm{~h}$. Both growth and product formation $\left(17.93 \mathrm{U} \mathrm{mL}^{-1}\right)$ were remarkably high at $45^{\circ} \mathrm{C}$ and both were coupled under optimum working conditions. Product yield of BGL from the mutant M7 (1556.5 $\mathrm{U} \mathrm{g}^{-1}$ dry corncobs) was significantly higher than the values reported on all fungal and bacterial systems. Mutation had thermo-stabilization influence on the organism and mutant required lower activation energy for growth and lower magnitudes of enthalpy and entropy for product formation than those demanded by the wild organism, other mesophilic and thermo-tolerant organisms. In the inactivation phase, the organisms needed lower values of activation energy, enthalpy and entropy for product formation equilibrium, confirming thermophilic nature of metabolic network possessed by the mutant organism.
\end{abstract}

Key words: $\beta$-Glucosidase, enthalpy, entropy, hemicellulose, kinetics, regulation, submerged fermentation

\section{INTRODUCTION}

B-Glucosidase (EC. 3.2.1.21) occurs in several organisms, performing several functions in nature. It catalyzes the hydrolytic cleavage of ß-glycosidic linkages in glycosides and cellobiose to glucose. Hydrolytic capacity is dependent on the source of enzyme, physiological function and the localization of enzyme. Fungi and bacteria producing high $\beta$-glucosidase (BGL) activities have attracted considerable attraction because of potential applications to release flavour compounds such as terpenes from odorless non-volatile glycosidic precursors in fruit juices and wines (33), release phenolic compounds with antioxidant, neutraceutical and flavouring properties from their glycosilated forms in plants among other industrial applications $(9,32)$.
Renewable natural resources such as cellulose and xylans (42) are abundant in many agricultural wastes. The enzymatic degradation of waste cellulose by fungal enzymes has been suggested as a feasible alternative for the conversion of lignocellulosics into fermentable sugars and fuel ethanol. This bioconversion is conducted through the combined action of cellulolytic enzymes. Since the activities of cellulase complex are relatively low, this vast resource is not properly utilized. Major constraint is low titre of BGL, which hydrolyzes cellobiose to Dglucose and relieves the end product inhibition of exo-glucanase (EC. 3.2.1.91), and endo-glucanase (EC. 3.2.1.4), aids in cellulase induction and cellulose hydrolysis. BGL from Aspergillus spp. are supplemented to commercial cellulase preparations from Trichoderma reesei, deficient in BGL. Aspergillus spp. are

*Corresponding Author. Mailing address: National Institute for Biotechnology and Genetic Engineering (NIBGE) P.O. Box 577, Faisalabad, Pakistan. Fax: + 9241 651472. E-mail: saib_2132003@yahoo.com 
mesophilic moulds and their BGL may be less thermo-stable than that derived from thermophilic moulds (1). Enzymes isolated from thermophilic microorganisms are not only thermo-stable, but also are often resistant to and active in the presence of organic solvents and detergents (3). The technological use of thermophiles still faces several challenges, since knowledge on the diversity, genetics, and physiology of such organisms is generally poor (36). Thermophiles or the genes derived from them are, however, still the preferred source for thermo-stable enzymes.

Humicola lanuginosa, a thermophilic mould, has developed a complex battery of glycosidases to deal with substrates possessing extensive micro-heterogeneities. Strains of $H$. lanuginosa have been applied for biobleaching of pulp $(18,42)$ and may be good sources of thermostable $\beta$-glucosidase for supplementation of cellulase preparation of Trichoderma reesei.

The production of enzymes is influenced by induction and catabolite repressions, which alter transcription with CreA protein, a transcriptional repressor of genes involved in metabolic processes other than glucose $(10,19,20)$ and AceI and Ace2 proteins $(6,7)$ in $T$. reesei. Thus mutations in regions linked to the control of genes creA, aceI and ace 2 may be a way to gain variant fungi with enhanced cellulase secretion. Mutagenesis followed by selection on DG has been widely used to isolate repression-resistant variants (5). This sort of mutagenesis also confers enhanced secretion of proteins in the culture medium (4).

In Pakistan, large amounts of agro-industrial residues namely sugarcane bagasse, wheat straw, wheat bran, and corncobs are generated every year by diverse economic activities, supporting the biotechnological interest on their utilization as raw materials in biotechnological processes (37). They could be utilized for bulk production of industrial products to meet the increasing consciousness of energy conservation. Submerged fermentation is an attractive method since all process variables can be easily controlled in this fermentation procedure while in SSF, the lower mass transfer processes, related to gases and nutrients diffusion, and temperature take place (4).

This work examines the potential of a DG resistant mutant of H. lanuginosa for production of BGL and evaluates the key role of substrate, nitrogen source, $\mathrm{pH}$ of the medium and temperature in the life of a thermophilic mould during growth and to maximize the production of BGL as reported in other mutant organisms $(12,15,21)$.

\section{MATERIALS AND METHODS}

\section{Chemicals}

All chemicals used in these studies were purchased from Sigma Chemical Company, Saint Louis, Missouri, USA.

\section{Micro-organism}

Strain of $H$. lanuginosa NIBGE F220 was maintained on potato-dextrose agar plates and slants (30). For inoculum preparation, Vogel's medium (containing $0.5 \%$ trisodium citrate, $0.2 \% \quad \mathrm{NH}_{4} \mathrm{NO}_{3}, 0.5 \% \quad \mathrm{KH}_{2} \mathrm{PO}_{4}, 4 \%\left(\mathrm{NH}_{4}\right)_{2} \mathrm{SO}_{4}, 0.02 \%$ $\mathrm{MgSO}_{4} .7 \mathrm{H}_{2} \mathrm{O}, 1 \%$ glucose, $0.1 \%$ yeast extract) $90 \mathrm{~mL}(\mathrm{pH} 6.5$ ) $\mathrm{HCl}$-washed glass beads ( 20 in number), was made up in $500 \mathrm{~mL}$ flasks. The whole contents ware sterilized at $121^{\circ} \mathrm{C}$ for $30 \mathrm{~min}$. The flasks were inoculated with $10 \mathrm{~mL}$ of spore suspension $(3 \times$ $10^{6} \mathrm{CFU} \mathrm{mL} \mathrm{m}^{-1}$ ) of $H$. lanuginosa strains and incubated overnight at $45^{\circ} \mathrm{C}$ on a gyratory shaker $(150 \mathrm{rpm})$. For enzyme production one gram of solid substrates (Table 1) $(100-500 \mu \mathrm{m}$ particle size) were added to $45 \mathrm{~mL}$ Vogel's medium (pH 6.5) in $250 \mathrm{~mL}$ Erlenmeyer's flasks in triplicate and whole contents were sterilized. Non-induced (glucose-grown inoculum) and washed conidial suspensions $(5 \mathrm{~mL})$ at $3 \mathrm{~g}$ cells $\mathrm{L}^{-1}$ were used to inoculate the enzyme production medium. The inoculated flasks were incubated at $45 \pm 2.0^{\circ} \mathrm{C}$ for $72 \mathrm{~h}$ in an orbital shaker $(150 \mathrm{rpm})$. After each $8 \mathrm{~h}$, the contents were homogenized and then passed through Whatman 40 filter paper to remove substrate. The filtrate was centrifuged $\left(12,000 \mathrm{x} \mathrm{g}\right.$ for $\left.10 \mathrm{~min}, 10^{\circ} \mathrm{C}\right)$ and substrate free enzyme extract was used for following the enzyme activities. Substrate was washed thoroughly and dried at $95^{\circ} \mathrm{C}$ to a constant weight. The moisture content was determined from the weight loss after drying the sample at $80^{\circ} \mathrm{C}$ for 2 days.

\section{Mutagenesis and selection}

H. lanuginosa conidial suspension maintained at $3 \times 10^{6}$

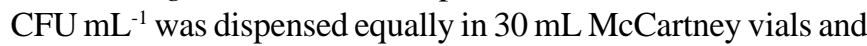
exposed to different doses (0.4-1.4 kGray) of $\gamma$-rays in gamma cell radiation chamber (Mark-IV). The survival curve was prepared and exposure dose of 1.2 kGray giving 3-log kill was selected for mutation of the organism. The mutants were selected by permitting expression in broth containing DG $(0.6 \%)$ and cellobiose $(1 \%)$ before plating on DG-esculin-ferric ammonium citrate agar medium (37) from which colony showing faster and bigger blackening zones was selected.

\section{Enzyme assays}

B-Glucosidase activity was determined using $p$ nitrophenyl B-D-glucopyranoside (pNPG) as substrate (37). The reaction mixture $(600 \mu \mathrm{L})$ contained $200 \mu \mathrm{L}$ of citrate buffer (50 mM, pH 4.5), $200 \mu \mathrm{L}$ of pNPG ( $5 \mathrm{mM})$, and $200 \mu \mathrm{L}$ culture supernatant. After incubation at $40^{\circ} \mathrm{C}$ for $10 \mathrm{~min}$, the reaction was stopped by adding $3 \mathrm{~mL}$ of cold sodium carbonate (500 $\mathrm{mM}, \mathrm{pH} 10$ ) and volume was made up to $6 \mathrm{~mL}$ with distilled water. The activity of BGL was estimated spectrophotometrically by reading the absorbance of the liberated $p$-nitrophenol at $400 \mathrm{~nm}$. One U of BGL has been defined as the amount of enzyme that releases $1-\mu \mathrm{mol}$ para-nitrophenol equivalents per $\mathrm{mL}$ per min.

\section{Effect of varying $\mathrm{pH}$ and temperature on enzyme production}

The effect of initial $\mathrm{pH}$ of the fermentation medium on enzyme production parameters was studied in shake flasks 
Table 1. Comparative $\beta$-glucosidase formation parameters of $H$. lanuginosus $(\mathrm{P})$ and its DG mutant $\mathrm{M} 7(\mathrm{M})$ following growth on different substrates in Shake flask fermentation at $45^{\circ} \mathrm{C}$ in Vogel's basal salt medium.

\begin{tabular}{|c|c|c|c|c|c|c|}
\hline & & $\mathrm{Q}_{\mathrm{P}}\left(\mathrm{UL}^{-1} \mathrm{~h}^{-1}\right)$ & $\mathrm{Y}_{\mathrm{P} / \mathrm{X}}\left(\mathrm{U} \mathrm{g}^{-1}\right)$ & $\mathrm{Y}_{\mathrm{P} / \mathrm{S}}\left(\mathrm{U} \mathrm{g}^{-1}\right)$ & $\mathrm{q}_{\mathrm{p}}\left(\mathrm{U} \mathrm{g}^{-1} \mathrm{~h}^{-1}\right)$ & Enzyme titer $\left(\mathrm{U} \mathrm{mL}^{-1}\right)$ \\
\hline Arabinose & PM & $18.11^{\circ} 142.2^{\mathrm{g}}$ & $68.7^{\mathrm{n}} 416.7^{\mathrm{i}}$ & $27.5^{\mathrm{q}} 175.0^{\mathrm{jk}}$ & $13.1^{\mathrm{p} 83.3^{\mathrm{jk}}}$ & $0.55^{\mathrm{p}} 3.50^{\mathrm{jk}}$ \\
\hline Xylose & PM & $77.3^{1} 180.2^{\mathrm{d}}$ & $239.6560 .0^{\mathrm{g}}$ & $115.0^{\mathrm{no}} 280.0^{\mathrm{g}}$ & $45.5^{\mathrm{no}} 117.6^{\mathrm{gh}}$ & $2.32^{\mathrm{mno}} 5.60^{\mathrm{h}}$ \\
\hline Sorbose & PM & $9.0^{p} 78.9^{1}$ & $51.2^{\mathrm{n}} 487.8^{\mathrm{h}}$ & $20.5^{\mathrm{q}} 200.0^{\mathrm{i}}$ & $9.7^{\mathrm{p}} 102.4^{\mathrm{hij}}$ & $0.41^{\mathrm{p}} 4.01^{\mathrm{ij}}$ \\
\hline Mannose & PM & $11.4^{\mathrm{op}} 60.5^{\mathrm{m}}$ & $48.9^{n} 316.3^{k}$ & $23.0^{\mathrm{q}} 155.0^{\mathrm{kl}}$ & $10.8^{\mathrm{p}} 72.8^{\mathrm{klm}}$ & $0.46^{\mathrm{p}} 3.10^{\mathrm{km}}$ \\
\hline Fructose & PM & $37.7^{\mathrm{n}} 126.4^{\mathrm{hi}}$ & $180.8^{\mathrm{m}} 479.2^{\mathrm{h}}$ & $85.0^{\mathrm{p}} 230.0^{\mathrm{h}}$ & $36.2^{\circ} 100.6^{\mathrm{hij}}$ & $1.72^{\circ} 4.61^{\mathrm{i}}$ \\
\hline Galactose & PM & $16.0^{\circ} 127.4^{\mathrm{hi}}$ & $42.7^{\mathrm{n}} 408.2^{\mathrm{i}}$ & $20.5^{\mathrm{q}} 200.0^{\mathrm{i}}$ & $9.4^{\mathrm{p} 93.9^{\mathrm{ij}}}$ & $0.41^{\mathrm{p}} 4.00^{\mathrm{ij}}$ \\
\hline Glucose & PM & $16.2^{\circ} 111.3^{j}$ & $39.0^{\mathrm{n}} 367.9^{\mathrm{j}}$ & $19.5^{\mathrm{q}} 195.0^{\mathrm{ij}}$ & $8.6^{\mathrm{p} 88.3^{\mathrm{jk}}}$ & $0.39^{\mathrm{p}} 3.90^{\mathrm{ijk}}$ \\
\hline Lactose & PM & $43.2^{\mathrm{n}} 196.6^{\mathrm{c}}$ & $325.0^{\mathrm{k}} 829.3^{\mathrm{f}}$ & $130.0^{\mathrm{mn}} 340.0^{\mathrm{f}}$ & $58.5^{\mathrm{mn}} 165.9^{\mathrm{f}}$ & $2.60^{\mathrm{mn}} 6.80^{\mathrm{ef}}$ \\
\hline Cellobiose & PM & $43.7^{\mathrm{n}} 204.9^{\mathrm{b}}$ & $317.1^{\mathrm{k}} 825.6^{\mathrm{f}}$ & $130.0^{\mathrm{mnn}} 355.0^{\mathrm{f}}$ & $57.1^{\mathrm{mn}} 198.1^{\mathrm{e}}$ & $2.61^{\mathrm{mn}} 7.13^{\mathrm{e}}$ \\
\hline Maltose & PM & $98.8^{\mathrm{k}} 190.6^{\mathrm{c}}$ & $262.5^{1} 817.1^{\mathrm{f}}$ & $105.0^{\mathrm{op}} 335.0^{\mathrm{f}}$ & $47.2^{\mathrm{no}} 155.3^{\mathrm{f}}$ & $2.12^{\mathrm{no}} 6.73^{\mathrm{ef}}$ \\
\hline Sucrose & PM & $40.0^{\mathrm{n}} 167.0^{\mathrm{e}}$ & $295.9^{\mathrm{k}} 549.0^{\mathrm{g}}$ & $145.0^{\operatorname{lm} 280.0^{\mathrm{g}}}$ & $68.1^{\operatorname{lm} 131.8^{\mathrm{g}}}$ & $2.91^{\operatorname{lmn}} 5.62^{\mathrm{gh}}$ \\
\hline Corn cobs & PM & $182.3^{\mathrm{d}} 212.8^{\mathrm{a}}$ & $1716.9^{c} 2614.0^{a}$ & $844.0^{\mathrm{c}} 1342.3^{\mathrm{a}}$ & $274.7^{\mathrm{c}} 470.5^{\mathrm{a}}$ & $9.25^{\mathrm{d}} 14.91^{\mathrm{a}}$ \\
\hline Wheat straw & PM & $130.0^{\mathrm{h}} 158.3^{\mathrm{f}}$ & $1454.5^{\mathrm{d}} 2434.8^{\mathrm{b}}$ & $695.6^{\mathrm{d}} 1154.6^{\mathrm{b}}$ & $232.7^{\mathrm{d}} 413.9^{\mathrm{b}}$ & $6.43^{\text {fg }} 12.66^{\mathrm{b}}$ \\
\hline Xylan & $\mathrm{PM}$ & $122.2^{\mathrm{i}} 194.8^{\mathrm{c}}$ & $580.0^{\mathrm{g}} 1019.2^{\mathrm{e}}$ & $290.0^{g} 530.0^{\mathrm{e}}$ & $110.2^{\mathrm{hi}} 203.8^{\mathrm{e}}$ & $5.88^{\text {gh }} 10.64^{\mathrm{c}}$ \\
\hline $\operatorname{LSD}(P \leq 0.05)$ & & 6.349 & 30.210 & 20.600 & 17.690 & 0.764 \\
\hline Significant & & HS & HS & HS & HS & $\mathrm{HS}$ \\
\hline
\end{tabular}

Each value is a mean of three replicates. Values followed by different letters differ significantly at $p \leq 0.05$.

$\mathrm{Q}_{\mathrm{P}}=$ enzyme formation rate, $\mathrm{Y}_{\mathrm{P} / \mathrm{X}}=$ specific enzyme yield, $\mathrm{Y}_{\mathrm{P} / \mathrm{S}}=$ enzyme yield based on substrate utilized, and $\mathrm{q}_{\mathrm{P}}=$ specific enzyme formation rate.

by varying $\mathrm{pH}(5.0-7.5)$ while maintaining optimum temperature and other growth supporting conditions. For studying the effect of temperature, the experiments were repeated in shake flasks (as above) and incubated on an orbital shaker (120 rpm) at $30,35,40,45,50,55,60$ and $65^{\circ} \mathrm{C}$ for up to a period of $72 \mathrm{~h}$.

\section{Protein and saccharide determination}

The protein in the enzyme preparation was quantified by the Bradford method (11) using bovine serum albumin as the standard. Reducing sugars were estimated colourimetrically with 3,5-dinitrosalicylic acid after Miller (34) using xylose as a standard. Solid material in the fermentation broth was determined gravimetrically.

\section{Mycelial biomass}

Biomass was determined indirectly from the measurement of protein content (22).

\section{Determination of kinetic parameters}

All kinetic and thermodynamic parameters were determined as described previously (2).

\section{Statistical analysis}

MStat C software was used to do the statistical analysis as described earlier (39).

\section{RESULTS AND DISCUSSION}

Glucose in the growth medium of moulds generally represses enzyme production, and only after exhaustion of glucose, the fungi start the production of $B$-glucosidase (BGL). In agreement with these results, the wild culture of $H$. lanuginosa produced a constitutive basal level of BGL $\left(0.39 \mathrm{U} \mathrm{mL}^{-1}\right)$ in the presence of glucose (Fig. 1), and the higher enzyme production started only after glucose consumption. But in the case of DG-resistant mutant (M7), BGL formation started from the initial stages of growth and that mutant organism supported 10-fold higher BGL production on glucose in basal Vogel's medium. The mutation conferred catabolite repression resistance to some extent on M7 and significantly enhanced transport of enzyme in the medium. Thus, the production of extra-cellular BGL by $H$. lanuginosa was inducible and controlled by catabolite repression in the wild organism, caused by mono-saccharides (Table 1). The product formation parameters like enzyme formation rate $\left(\mathrm{Q}_{\mathrm{P}}\right)$, specific enzyme yield $\left(\mathrm{Y}_{\mathrm{P} / \mathrm{X}}\right)$, enzyme yield $\left(\mathrm{Y}_{\mathrm{P} / \mathrm{S}}\right)$, specific enzyme formation rate $\left(\mathrm{q}_{\mathrm{P}}\right)$ and enzyme titer are presented in Table 1.

\section{Kinetics of enzyme production following growth on different carbon sources}

The kinetics of BGL production by un-induced cells of $H$. lanuginosa were determined after growth in basal Vogel's culture 
medium containing different carbon sources in time course studies as described earlier (15) and all kinetic parameters for product formation were determined (Table 1). Interaction of all treatments and all kinetic parameters was highly significant. The specific growth rate $(\mu)$, cell mass formation rate $\left(Q_{x}\right)$, substrate uptake rates $\left(\mathrm{Q}_{\mathrm{S}}\right)$, cell yield coefficient $\left(\mathrm{Y}_{\mathrm{X} / \mathrm{S}}\right)$ and specific substrate uptake rates $\left(\mathrm{q}_{\mathrm{s}}\right)$ are shown in Table 2 . These parameters were considered the factors that might control enzyme synthesis by different substrates (29). There were significant variation in the specific growth rate $(\mu)$, cell mass formation rate $\left(\mathrm{Q}_{\mathrm{x}}\right)$ and the substrate uptake rate $\left(\mathrm{Q}_{\mathrm{S}}\right)$ during growth on all carbon sources and permitted significantly ( $p \leq$ $0.05)$ larger variations on synthesis of BGL. The values of $\mathrm{q}_{\mathrm{s}}$ from glucose $\left(0.45 \mathrm{~g} \mathrm{~g}^{-1} \mathrm{~h}^{-1}\right)$, cellobiose $\left(0.47 \mathrm{~g} \mathrm{~g}^{-1} \mathrm{~h}^{-1}\right)$ and corncobs $\left(0.36 \mathrm{~g} \mathrm{~g}^{-1} \mathrm{~h}^{-1}\right)$ were significantly $(p \leq 0.05)$ different and exerted remarkable impact on the enzyme titre $\left(\mathrm{U} \mathrm{mL}^{-1}\right)$, enzyme yields and productivities (Table 1).

Specific enzyme yield $\left(\mathrm{Y}_{\mathrm{P} / \mathrm{X}}\right)$ was $1716.9 \mathrm{U} \mathrm{g} \mathrm{cells}^{-1}$ on corncobs and only 39.0 $\mathrm{U} \mathrm{g} \mathrm{cells}^{-1}$ (basal enzyme activity) on glucose (non-inducer). The induction ratio, defined as the ratio of activity supported by inducers to basal activity, was 2.46, 7.70 and 32.06 on mono-saccharides, di-sccharides and polysaccharides respectively in the case of wild organism. Mutation narrowed down this induction ratio, which on monosaccharides, disaccharides and complex substrates was 1.06,

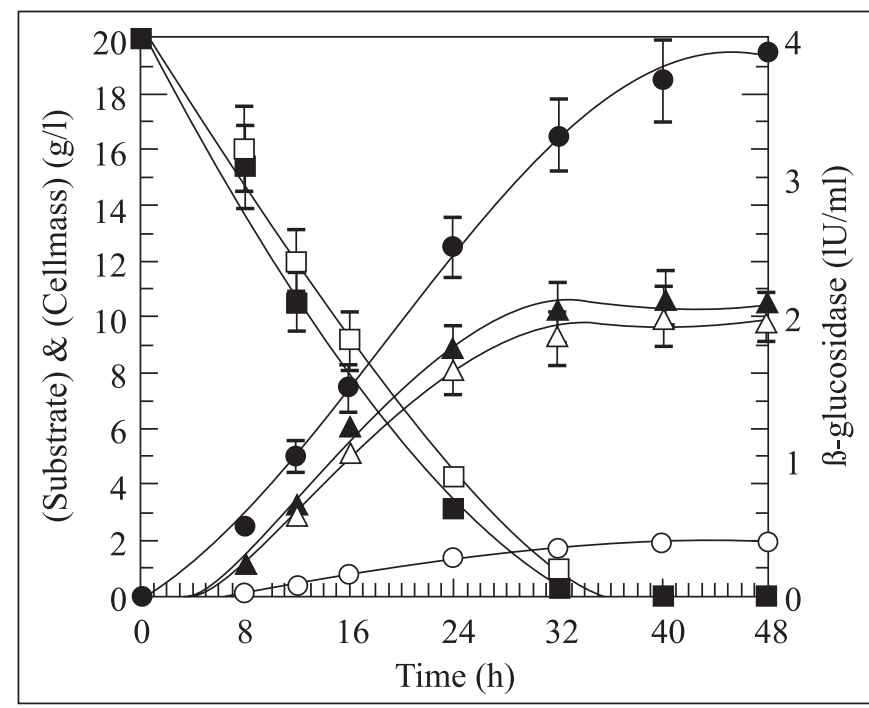

Figure 1. Time course of $ß$-glucosidase production on glucose basal medium in shaken cultures. The initial $\mathrm{pH}$ of the medium, inoculum size, and temperature were $6.5,10 \mathrm{~mL} 100 \mathrm{~mL}^{-1}$ substrate and $45^{\circ} \mathrm{C}$ respectively. $(O)=\beta$-glucosidase, $(\Delta)=$ cell mass, $(\square)$ $=$ substrate for the parental organism but closed symbols are for the mutant M7. Error bars show standard deviation among three observations.

Table 2. Comparative substrate consumption parameters of H. lanuginosus (P) and its DG mutant M7 (M) following growth on different substrates in Shake flask fermentation at $45^{\circ} \mathrm{C}$ in Vogel's basal salt medium

\begin{tabular}{|c|c|c|c|c|c|c|}
\hline & & $\mu\left(h^{-1}\right)$ & $\mathrm{Q}_{\mathrm{x}}\left(\mathrm{g} \mathrm{L}^{-1} \mathrm{~h}^{-1}\right)$ & $\mathrm{Q}_{S}\left(\mathrm{~g} \mathrm{~L}^{-1} \mathrm{~h}^{-1}\right)$ & $\mathrm{Y}_{\mathrm{X} / \mathrm{S}}\left(\mathrm{g} \mathrm{g}^{-1}\right)$ & $\mathrm{q}_{\mathrm{s}}\left(\mathrm{g} \mathrm{g}^{-1} \mathrm{~h}^{-1}\right)$ \\
\hline Arabinose & PM & $0.19^{\mathrm{ef}} 0.20^{\mathrm{de}}$ & $0.28^{\mathrm{j}} 0.32^{\mathrm{hi}}$ & $0.68^{\mathrm{h}} 0.77^{\mathrm{ef}}$ & $0.40^{\mathrm{i}} 0.42^{\mathrm{gh}}$ & $0.47^{\mathrm{bc}} 0.48^{\mathrm{b}}$ \\
\hline Xylose & PM & $0.19^{\mathrm{ef}} 0.21^{\mathrm{cd}}$ & $0.23^{\mathrm{m}} 0.35^{\mathrm{fg}}$ & $0.55^{1} 0.80^{d}$ & $0.48^{\mathrm{ef}} 0.50^{\mathrm{cd}}$ & $0.40^{\mathrm{h}} 0.42^{\mathrm{g}}$ \\
\hline Sorbose & $\mathrm{PM}$ & $0.19^{\mathrm{ef}} 0.21^{\mathrm{cd}}$ & $0.31^{\mathrm{i}} 0.39^{\mathrm{d}}$ & $0.61^{\mathrm{j}} 0.78^{\mathrm{e}}$ & $0.40^{\mathrm{i}} 0.41^{\mathrm{hi}}$ & $0.48^{\mathrm{b}} 0.51^{\mathrm{a}}$ \\
\hline Mannose & PM & $0.22^{\mathrm{bc}} 0.23^{\mathrm{ab}}$ & $0.37^{\mathrm{e}} 0.41^{\mathrm{c}}$ & $0.76^{\mathrm{f}} 0.93^{\mathrm{b}}$ & $0.47^{\mathrm{f}} 0.49^{\mathrm{de}}$ & $0.47^{\mathrm{bc}} 0.47^{\mathrm{bc}}$ \\
\hline Fructose & PM & $0.20^{\mathrm{de}} 0.21^{\mathrm{cd}}$ & $0.26^{\mathrm{j} k} 0.35^{\mathrm{f}}$ & $0.63^{\mathrm{i}} 0.85^{\mathrm{c}}$ & $0.47^{\mathrm{f}} 0.48^{\mathrm{ef}}$ & $0.43^{\mathrm{fg}} 0.44^{\mathrm{ef}}$ \\
\hline Galactose & PM & $0.22^{\mathrm{bc}} 0.23^{\mathrm{ab}}$ & $0.38^{\mathrm{de}} 0.45^{\mathrm{b}}$ & $0.76^{\mathrm{f}} 0.96^{\mathrm{a}}$ & $0.48^{\mathrm{ef}} 0.49^{\mathrm{de}}$ & $0.46^{\mathrm{cd}} 0.47^{\mathrm{bc}}$ \\
\hline Glucose & $\mathrm{PM}$ & $0.22^{\mathrm{bc}} 0.24^{\mathrm{a}}$ & $0.37^{\mathrm{de}} 0.47^{\mathrm{a}}$ & $0.72^{\mathrm{g}} 0.97^{\mathrm{a}}$ & $0.50^{\mathrm{cd}} 0.53^{\mathrm{a}}$ & $0.44^{\mathrm{ef}} 0.45^{\mathrm{de}}$ \\
\hline Lactose & PM & $0.18^{\mathrm{fg}} 0.20^{\text {de }}$ & $0.26^{\mathrm{j} k} 0.33^{\mathrm{gh}}$ & $0.52^{\mathrm{m}} 0.69^{\mathrm{h}}$ & $0.40^{\mathrm{i}} 0.41^{\mathrm{hi}}$ & $0.45^{\mathrm{de}} 0.48^{\mathrm{b}}$ \\
\hline Celloboise & PM & $0.18^{\mathrm{fg}} 0.20^{\mathrm{de}}$ & $0.24^{\mathrm{lm}} 0.32^{\mathrm{hi}}$ & $0.58^{\mathrm{k}} 0.73^{\mathrm{g}}$ & $0.41^{\mathrm{hi}} 0.43^{\mathrm{g}}$ & $0.44^{\mathrm{ef}} 0.47^{\mathrm{bc}}$ \\
\hline Maltose & $\mathrm{PM}$ & $0.18^{\mathrm{fg}} 0.19^{\mathrm{ef}}$ & $0.26^{\mathrm{jk}} 0.32^{\mathrm{hi}}$ & $0.68^{\mathrm{h}} 0.72^{\mathrm{g}}$ & $0.40^{\mathrm{i}} 0.41^{\mathrm{hi}}$ & $0.46^{\mathrm{cd}} 0.46^{\mathrm{cd}}$ \\
\hline Sucrose & $\mathrm{PM}$ & $0.23^{\mathrm{ab}} 0.24^{\mathrm{a}}$ & $0.38^{\mathrm{de}} 0.47^{\mathrm{a}}$ & $0.76^{\mathrm{f}} 0.97^{\mathrm{a}}$ & $0.49^{\mathrm{de}} 0.51^{\mathrm{bc}}$ & $0.47^{\mathrm{bc}} 0.47^{\mathrm{bc}}$ \\
\hline Corn cobs & PM & $0.16^{\mathrm{h}} 0.18^{\mathrm{fg}}$ & $0.12^{\circ} 0.16^{\mathrm{n}}$ & $0.31^{\mathrm{p}} 0.40^{\mathrm{o}}$ & $0.48^{\mathrm{ef}} 0.50^{\mathrm{cd}}$ & $0.33^{\mathrm{k}} 0.36^{\mathrm{j}}$ \\
\hline Wheat straw & PM & $0.16^{\mathrm{h}} 0.17^{\mathrm{gh}}$ & $0.16^{\mathrm{n}} 0.25^{\mathrm{kl}}$ & $0.32^{\mathrm{p}} 0.44^{\mathrm{n}}$ & $0.47^{\mathrm{f}} 0.47^{\mathrm{f}}$ & $0.34^{\mathrm{k}} 0.36^{\mathrm{j}}$ \\
\hline Xylan & $\mathrm{PM}$ & $0.19^{\mathrm{ef}} 0.20^{\mathrm{de}}$ & $0.26^{\mathrm{j} k} 0.32^{\mathrm{hi}}$ & $0.60^{\mathrm{i}} 0.76^{\mathrm{f}}$ & $0.50^{\mathrm{cd}} 0.52^{\mathrm{ab}}$ & $0.38^{i} 0.38^{i}$ \\
\hline $\operatorname{LSD}(P \leq 0.05)$ & & 0.01636 & 0.01636 & 0.01636 & 0.01636 & 0.01636 \\
\hline Significance & & HS & HS & HS & HS & HS \\
\hline
\end{tabular}

Each value is a mean of three replicates. Values followed by different letters differ significantly at $p \leq 0.05$.

$\mu=$ specific growth rate, $Q_{X}=$ cell mass formation rate, $Q_{S}=$ substrate uptake rate, $Y_{X / S}=$ cell yield coefficient and $q_{s}=$ specific substrate uptake rate. 
2.05 and 5.50 respectively, in the case of mutant M7. Thus mutation decreased induction ratio by a factor 2.3, 3.8, 5.8-fold in the M7 and is a significantly high achievement. Corncobs is an insoluble substrate and is too difficult to pump through pipelines for continuous fermentation. Cellobiose was the best soluble disaccharide but is extremely expensive. Among disaccharides, sucrose (the one of the best substrate among soluble substrates) in molasses may be economically viable inducer for mass production of this enzyme as already reported in Kluyveromyces marxianus (24). Further studies are needed to develop a continuous process for enzyme production that would fulfill this requirement of the process. Best yield of BGL (Table 1) on corncobs is in good agreement with that reported earlier (17). The results presented are of considerable significance for further development of a suitable large-scale production process for maximal production of BGL by $H$. lanuginosa strains.

\section{Time course of production of $\beta$-glucosidase and carbon source utilization}

Enzyme production and substrate utilization from one representative substrate namely, xylan in shaken cultures is presented in Fig. 2. This figure and others (not presented) revealed that optimal production of BGL was reached within 64 $\mathrm{h}$ while other thermopilic fungi produced maximum activity after $120-140 \mathrm{~h}$ of fermentation $(8,18,21)$. These curves also indicated that production of enzyme was apparently growth-associated. Among potential inducers (Table 1) of BGL, lignocellulosic substrates, xylan, and xylose both induced the cells to produce BGL activity (because of lower substrate consumption parameters). It has been observed (26) that during growth on such polymeric carbon sources, high amount of mRNA for a particular enzyme is produced. This is attributed to reducing sugars accumulating slowly in the growth medium as unmetabolized principles to cause induction of xylanases as reported earlier (26).

Cost of substrate plays a major role in the economics of enzyme production (15). Hence approach to use cheaper lignocellulosic (corncobs) rather than opting for expensive cellobiose will decrease cost of BGL production. We may also opt for sucrose in molasses as a cheaper substrate for BGL production in continuous culture.

\section{Effect of nitrogen sources}

Among the various nitrogen sources (ammonium nitrate, ammonium sulfate, di-ammonium phosphate, urea, and corn steep liquor) added at equimolar concentration to medium containing corncobs $(2 \% \mathrm{w} / \mathrm{v})$, corn steep liquor (CSL) favoured maximum BGL production, followed by urea in the absence of $\mathrm{pH}$ control. In this work, inorganic nitrogen sources (ammonium compounds) did not support a high level of BGL production comparable to CSL (Table 3). On the other hand, some studies

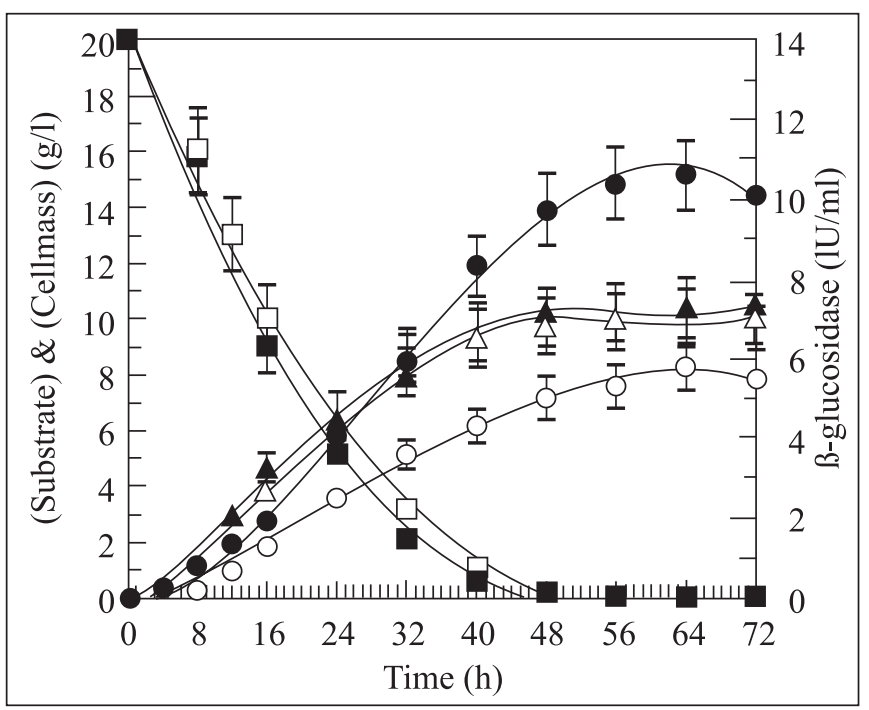

Figure 2. Time course of $\beta$-glucosidase production process in shaken culture during fermentation of xylan. The initial $\mathrm{pH}$ of the medium, inoculum size, and temperature were $6.5,10 \mathrm{~mL} 100$ $\mathrm{mL}^{-1}$ substrate and $45^{\circ} \mathrm{C}$ respectively. $(\mathrm{O})=\beta$-glucosidase, $(\Delta)$ $=$ cell mass, $(\square)=$ substrate for the parental organism but closed symbols are for the mutant M7. Error bars show standard deviation among three observations.

have found that inorganic nitrogen sources resulted in equal or higher BGL production than organic ones (9). Urea $(0.25 \% \mathrm{w} / \mathrm{v})$ favoured maximum pectinase production in Streptomyces sp. RCK-SC (27). The results (Table 3) indicate that the presence of CSL in the culture medium was essential to support enhanced global kinetic parameters. CSL, when used alone as carbon and nitrogen source, supported one tenth of the maximum activity supported by corncobs. In the presence of CSL, higher enzyme synthesis may have occurred due to the up-regulation of global nitrogen metabolism regulator, AreA $(8,19,26)$ and supported the work of other authors $(8,9,12,17)$. Corn steep liquor is an example of cheap nitrogen source successfully employed as complex nitrogen source in BGL production, contributing to further lower down the cost of production.

The utilization of agro-industrial residues as potential substrates for the production of BGL and other cellulase, hemicellulase and pectinase components has attracted much attention $(17,36)$, since it can contribute to lower the costs of enzyme production and also reduce the environmental pollution caused by the accumulation of lignocellulosic wastes. It was demonstrated that the best substrate-nitrogen source combination for BGL production $\left(15.2 \mathrm{U} \mathrm{mL}^{-1}\right)$ was the corncobs and CSL. Results showed that extra-cellular BGL activity continues to grow until the $3^{\text {rd }}$ day of cultivation, a considerable fall in the productivity is observed at this point. In this sense, 
Table 3. Comparative fermentation kinetic parameters of T. lanuginosus (P) and its DG mutant M7 (M) for ß-glucosidase formation following growth on corncobs containing Vogel's medium in presence of different nitrogen sources in shake flask cultivation under optimized cultivation conditions.

\begin{tabular}{lccccc}
\hline Nitrogen source** & & $\mathrm{Q}_{\mathrm{P}}\left(\mathrm{U} \mathrm{L}^{-1} \mathrm{~h}^{-1}\right)$ & $\mathrm{Y}_{\mathrm{P} / \mathrm{X}}\left(\mathrm{Ug} \mathrm{g}^{-1}\right)$ & $\mathrm{Y}_{\mathrm{P} / \mathrm{S}}\left(\mathrm{Ug}^{-1}\right)$ & $\mathrm{q}_{\mathrm{p}}\left(\mathrm{U} \mathrm{g}^{-1} \mathrm{~h}^{-1}\right)$ \\
\hline Ammonium nitrate & $\mathrm{PM}$ & $171.1^{\mathrm{d}} 212.9^{\mathrm{b}}$ & $1666.7^{\mathrm{f}} 2641.5^{\mathrm{b}}$ & $809.5^{\mathrm{f}} 1308.4^{\mathrm{b}}$ & $250.0^{\mathrm{f}} 422.6^{\mathrm{c}}$ \\
Ammonium sulphate & $\mathrm{PM}$ & $179.2^{\mathrm{d}} 204.5^{\mathrm{b}}$ & $1745.1^{\mathrm{e}} 2150.9^{\mathrm{c}}$ & $847.7^{\mathrm{ef}} 1065.4^{\mathrm{c}}$ & $261.8^{\mathrm{f}} 344.1^{\mathrm{d}}$ \\
Corn steep liquor & $\mathrm{PM}$ & $195.6^{\mathrm{c}} 261.6^{\mathrm{a}}$ & $1894.7^{\mathrm{d}} 3034.0^{\mathrm{a}}$ & $981.8^{\mathrm{d}} 1556.5^{\mathrm{a}}$ & $341.1^{\mathrm{d}} 576.5^{\mathrm{a}}$ \\
Diammonium phosphate & $\mathrm{PM}$ & $178.4^{\mathrm{d}} 210.4^{\mathrm{b}}$ & $1769.2^{\mathrm{de}} 2614.0^{\mathrm{b}}$ & $876.2^{\mathrm{e}} 1330.3^{\mathrm{b}}$ & $300.8^{\mathrm{e}} 470.5^{\mathrm{b}}$ \\
Urea & $\mathrm{PM}$ & $176.2^{\mathrm{d}} 209.5^{\mathrm{b}}$ & $1784.3^{\mathrm{def}} 2649.1^{\mathrm{b}}$ & $866.7^{\mathrm{ef}} 1324.6^{\mathrm{b}}$ & $285.5^{\mathrm{ef}} 450.4^{\mathrm{bc}}$ \\
LSD $(P \leq 0.05)$ & & 8.815 & 116.300 & 63.460 & 33.710 \\
Significance & & $\mathrm{HS}$ & $\mathrm{HS}$ & $\mathrm{HS}$ & $\mathrm{HS}$ \\
\hline
\end{tabular}

Each value is a mean of three replicates. Values followed by different letters differ significantly at $p$ d" 0.05 . For symbols see Table 2.

the cultivation period of 2 days was chosen for extra-cellular BGL production by $H$. lanuginosa strain. Corncobs and CSL are waste products of starch industry, with more than 16 million tons produced annually. Thus, they can be employed in composting processes, as sources of antioxidant compounds, for enzyme, ethanol and citric acid production, among other applications.

Product yield $\left(\mathrm{Y}_{\mathrm{P} / \mathrm{S}}\right)$, specific product yield $\left(\mathrm{Y}_{\mathrm{P} / \mathrm{X}}\right)$ and product formation rates $\left(\mathrm{Q}_{\mathrm{P}}\right)$ of $\mathrm{BGL}$ of $H$. lanuginosa (Table 3) are significantly higher than the values reported for Aspergilus spp., Trichoderma reesei RUT C30, other fungal cultures, different bacteria (37,45), E. coli and Saccharomyces cerevisiae recombinants harboring heterologous $\mathrm{bgl}$ gene (38), Thielavia terrestris and Themoascus crustaceus (41), Thermoascus aurantiacus (25), Humicola spp. (23), Thermomyces lanuginosus (31), other fungi and their DG resistant mutants $(8,21,45)$ though substrates used in referred studies were different. This comparison shows the superiority of DG resistant mutant (M7) for production of BGL.

\section{Effect of medium $\mathrm{pH}$}

The effect of initial culture medium $\mathrm{pH}$ on the global kinetic parameters of BGL production was investigated using corncobs (2\%) as the carbon source and CSL as the nitrogen source. The results in Fig. 3 show that optimal kinetic parameters were achieved in the range 6.5-6.75. Therefore $\mathrm{pH} 6.5$ was used in all further studies. The optimum $\mathrm{pH}$ of enzyme productivity was significantly different than that reported for most other BGLproducing microorganisms, namely, Monascus purpureus. (17) and Myceliophthora sp. (8).

\section{Effect of temperature}

Temperature is one of the most important variables. Temperature effects on fermentation performance of some selected organisms for product formation were reported previously $(35,43)$. Only few investigations were reported on

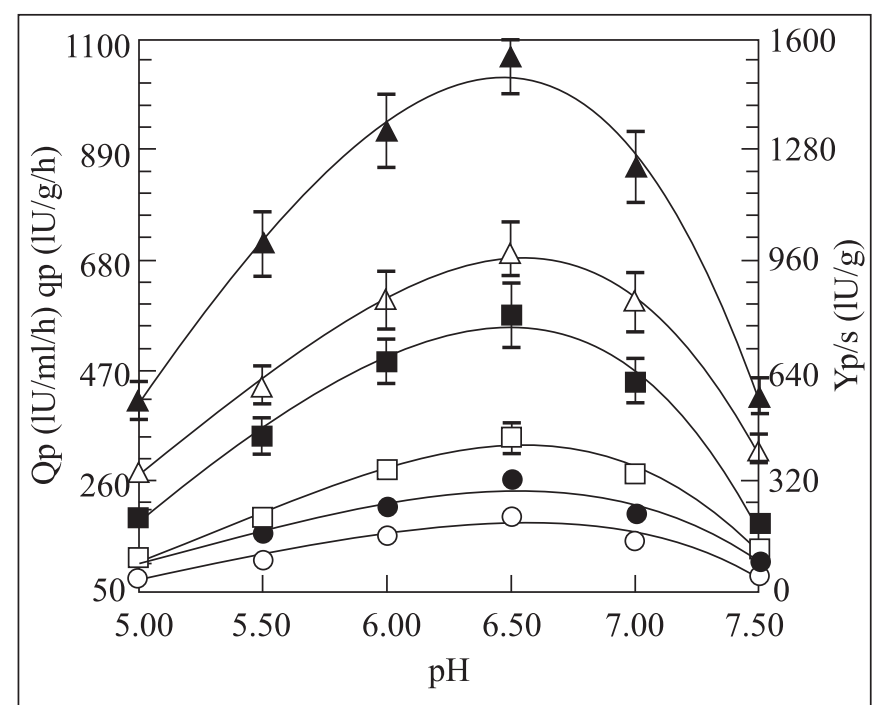

Figure 3. Effect of medium $\mathrm{pH}$ on product yield $\left(\mathrm{Y}_{\mathrm{P} / \mathrm{S}}, \Delta\right)$, volumetric productivity $\left(\mathrm{Q}_{\mathrm{P}}, \mathrm{O}\right)$ and specific productivity $\left(\mathrm{q}_{\mathrm{P}}\right.$, $\square$ ) of B-glucosidase following growth of parental (open symbols) and mutant M7 (closed symbols) of $H$. lanuginosa on corncobs-CSL medium using optimized conditions. Error bars show standard deviation among three observations.

the influence of temperature on the dynamic behaviour of $H$. lanuginosa during fermentation processes. Global fermentation parameters and thermodynamic parameters determination when product formation is occurring, may give information on the organism's metabolic network. The influence of temperature on the formation rate of BGL by mutant (M7) and wild strain of $H$. lanuginosa were studied with regard to the kinetic parameters related to biomass and BGL production and substrate utilization. The mutant organism (M7) was capable of rapid fermentation at temperature up to $65^{\circ} \mathrm{C}$ with significantly higher specific growth 
rate (Fig. 4a) which was better than those of other strains of $H$. lanuginosa grown at $45^{\circ} \mathrm{C}$ (3). The maximum specific growth rate, specific death rate of cells and the maximum product formation rate of both cells increased as the temperature increased up to $45-50^{\circ} \mathrm{C}$. Expressed by the Arrhenius relationship, the temperature dependence of these parameters is shown in Fig. 4a, 4b. The estimated values of activation energies for cell growth (46.56 and $78.59 \mathrm{~kJ} \mathrm{~mol}^{-1}$ for the mutant (M7) and wild cells respectively), BGL formation (143.59 and $171.94 \mathrm{~kJ} \mathrm{~mol}^{-1}$ ) and for cell death (42.20 and $60.86 \mathrm{~kJ} \mathrm{~mol}^{-1}$ respectively) and product inactivation (108.62 and $128.70 \mathrm{~kJ} \mathrm{~mol}^{-1}$ respectively) contrary to the higher values reported in literature for mesophilic organisms (138.9-177 kJ mol-1) (35). The values of activation energy during deactivation phase were lower than the values in the growth phase and confirm the findings of other authors for
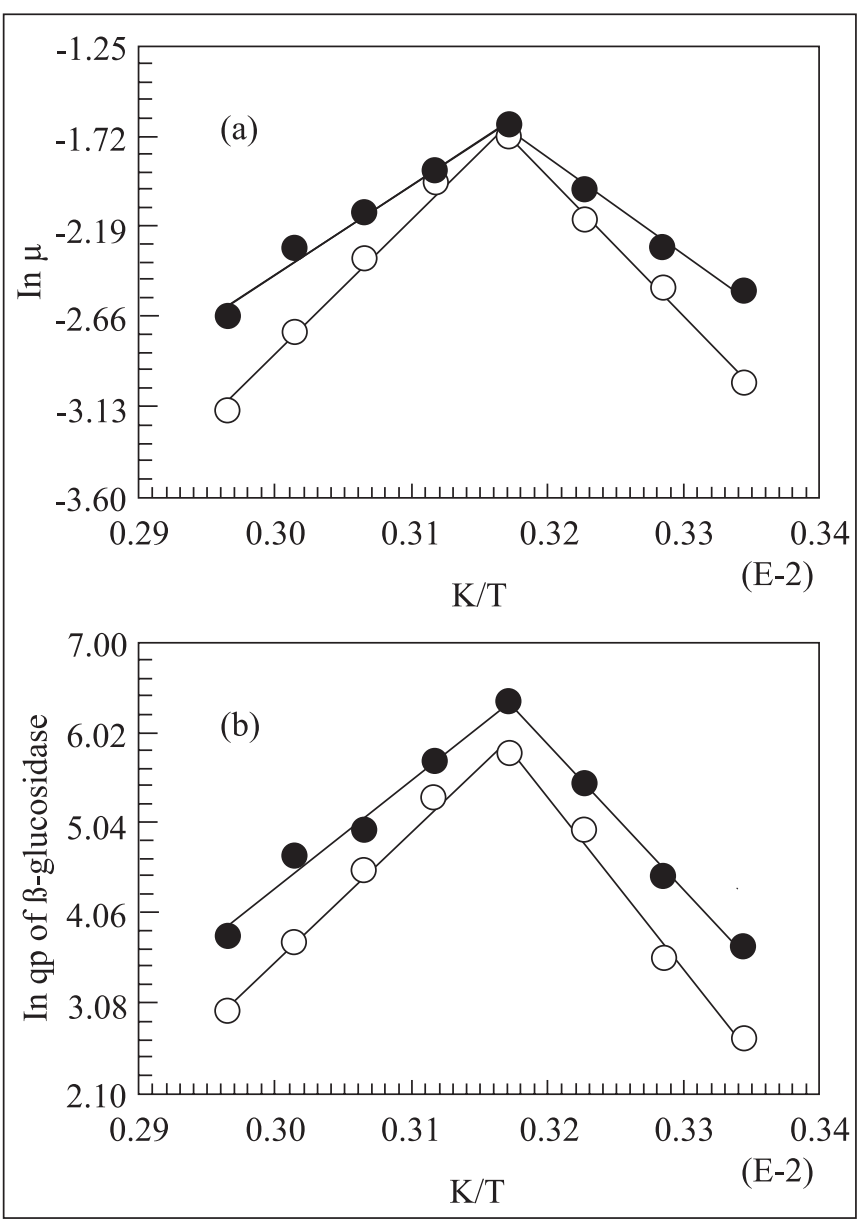

Figure 4. Effect of fermentation temperature on specific growth rate (a) and specific product formation rate (IU g cells $\left.{ }^{-1} \mathrm{~h}^{-1}\right)$ (b) of B-glucosidase from corncobs-CSL medium, following growth of the parental (open symbols) and mutant M7 (closed symbols) of $H$. lanuginosa. thermophilic organisms (2). Requirement of lower energy of activation $\left(\mathrm{E}_{\mathrm{a}}\right)$ for growth and product formation is considered indices of thermostable enzymes (1). The values of enthalpy for product formation (Table 4) indicated that the activation enthalpy $\left(140.92 \mathrm{~kJ} \mathrm{~mol}^{-1}\right)$ and activation entropy of formation of BGL $\left(250.2 \mathrm{~J} \mathrm{~mol}^{-1}\right)$ for the mutant M7 is lower than that for the wild organism and those for mesophilic organism (14) and thermotolerant Kluyveromyces marxianus (40).

The deleterious effects of high temperature were considered to be due to the denaturation of ribosomes and enzymes and problems associated with the fluidity of membranes (43). Thermal inactivation of metabolic network, when the organism is permitted to grow at temperature higher than that for maximum growth and product formation, may result in unfolding the enzymes of the metabolic network and normally occurs in two steps as shown below:

$$
\mathrm{N} \leftrightarrow \mathrm{U} \rightarrow \mathrm{I}
$$

Where $\mathrm{N}$ are the native enzymes, $\mathrm{U}$ are the unfolded enzymes that could be reversibly refolded upon cooling and I are the inactivated enzymes formed after prolonged exposure to heat and therefore can not be recovered on cooling.

The thermal denaturation of enzymes of the metabolic network is accompanied by the disruption of non-covalent linkages, including hydrophobic interactions, with concomitant increase in the enthalpy of activation (16). The opening up of the enzyme structures is accompanied by an increase in the disorder, randomness or entropy of activation (46). The related values of thermodynamic parameters were calculated from Fig. 5. The

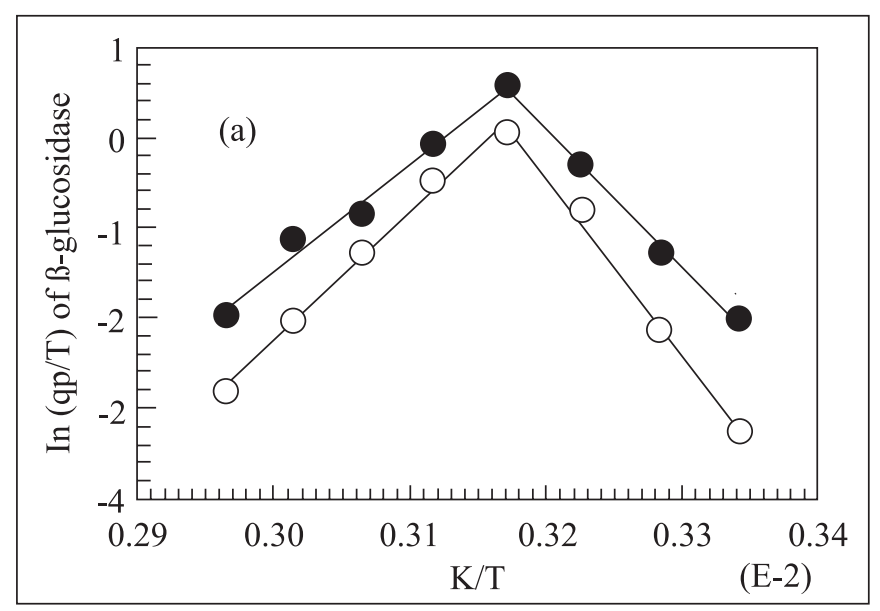

Figure 5. Determination of enthalpy and entropy for activation for product formation and inactivation equilibria of $B$ glucosidase in $H$. lanuginosa (open symbols) and its mutant M7 (closed symbols) following growth on corncobs-CSL medium ( $\mathrm{pH}$ 6.5) under optimized conditions. 
Table 4. Thermodynamic parameters* estimated by Arrhenius approach for batch formation and inactivation of ß-glucosidase formation metabolic network in cultures of $H$. lanuginosa $(\mathrm{P})$ and its DG mutant M7 (M) calculated from a graph between $\ln \left(\mathrm{q}_{\mathrm{p}} / \mathrm{T}\right)$ and $1 / \mathrm{T}$ as described in materials and methods.

\begin{tabular}{lcccc}
\hline & & Enthalpy $\left(\mathrm{kJ} \mathrm{mol}^{-1}\right)$ & Entropy $\left(\mathrm{J} \mathrm{mol}^{-1} \mathrm{~K}^{-1}\right)$ & $\mathrm{E}_{\mathrm{a}}$ for growth $\left(\mathrm{kJ} \mathrm{mol}{ }^{-1}\right)$ \\
\cline { 3 - 5 } B-glucosidase formation & PM & $183.05^{\mathrm{a}} 140.92^{\mathrm{b}}$ & $379.45^{\mathrm{a}} 250.25^{\mathrm{b}}$ & $78.59^{\mathrm{a}} 46.53^{\mathrm{c}}$ \\
Thermal inactivation & PM & $131.47^{\mathrm{b}} 111.38^{\mathrm{c}}$ & $-542.90^{\mathrm{c}}-609.33^{\mathrm{d}}$ & $60.86^{\mathrm{b}} 42.20^{\mathrm{d}}$ \\
& & & & \\
LSD $(P \leq 0.05)$ & 11.870 & 18.830 & 3.766 \\
Significance & $\mathrm{HS}$ & $\mathrm{HS}$ & $\mathrm{HS}$ \\
\hline
\end{tabular}

Each value is a mean of three independent studies. Values followed by different letters in each row are significantly different from each other at $p \leq 0.05$.

*Thermodynamic parameters were determined following growth on corncobs and CSL medium in temperature range of $30-65^{\circ} \mathrm{C}$.

mutant $\mathrm{M} 7$ needed $111.38 \mathrm{~kJ} \mathrm{~mol}^{-1}$ and $-609.33 \mathrm{~J} \mathrm{~mol}^{-1} \mathrm{~K}^{-1}$ values for enthalpy of deactivation $\left(\Delta \mathrm{H}_{\mathrm{d}}{ }^{*}\right)$ and entropy of deactivation $\left(\Delta \mathrm{S}_{\mathrm{d}}^{*}\right)$ respectively. The values of $\Delta \mathrm{H}_{\mathrm{d}}^{*}$ and $\Delta \mathrm{S}_{\mathrm{d}}{ }^{*}$ of BGL from a thermophilic culture of Aspergillus wentii were $125 \mathrm{~kJ} \mathrm{~mol}^{-1}$ and $65 \mathrm{~J} \mathrm{~mol}^{-1} \mathrm{~K}^{-1}(28)$. Thus difference of values for the BGL inactivation during growth for Aspergillus wentii BGL and $H$. lanuginosa mutant (M7) is markedly high, therefore, up to $65^{\circ} \mathrm{C}$, the process of BGL formation in mutant M7 was reasonably thermo-stable. These values are also significantly lower than those reported on thermo-stable glucoamylase from a mutant derivative of A. awamori (13) and those for the wild organism reported in this study (Table 4).

When enthalpy and entropy values for inactivation were calculated at each temperature, $\Delta \mathrm{S}^{*}, \Delta \mathrm{H}^{*}$ and $\Delta \mathrm{G}^{*}$ for BGL formation by mutant M7 had again lower values (Table 5) than those for the wild organism. This suggested that there was negligible defolding of enzymes of the metabolic network in the inactivation phase equilibrium as was that of BGL from $A$. wentii (28). All these findings suggested that mutation had significant effect in thermo-stabilization of the metabolic network of the mutant M7 during BGL production. This may have occurred due either to formation of chaperones or hyperglycosilation of enzymes of the production metabolic network as reported earlier (2).

\section{CONCLUSION}

From the data on induction studies, it was concluded that the availability of an inducer at a low level over a longer period of fermentation time would be more advantageous for B-

Table 5. Kinetic and thermodynamic parameters for formation of BGL by H. lanuginosa (P) and its DG mutant M7 (M) following growth on Vogel's medium containing corncobs and CSL.

\begin{tabular}{cccccc}
\hline Temperature $(\mathrm{K})$ & & $\mathrm{q}_{\mathrm{p}}\left(\mathrm{U} \mathrm{g}^{-1} \mathrm{~h}^{-1}\right)$ & $\Delta \mathrm{H}^{*}\left(\mathrm{~kJ} \mathrm{~mol}^{-1}\right)$ & $\Delta \mathrm{G}^{*}\left(\mathrm{~kJ} \mathrm{~mol}^{-1}\right)$ & $\Delta \mathrm{S}^{*}\left(\mathrm{~J} \mathrm{~mol}^{-1} \mathrm{~K}^{-1}\right)$ \\
\hline 303 & PM & $15.2^{\mathrm{k}} 40.9^{\mathrm{ji}}$ & $169.42^{\mathrm{a}} 141.07^{\mathrm{b}}$ & $88.03^{\mathrm{e}} 85.53^{\mathrm{gh}}$ & $268.61^{\mathrm{a}} 183.30^{\mathrm{c}}$ \\
308 & PM & $36.58666^{\mathrm{h}}$ & $169.38^{\mathrm{a}} 141.03^{\mathrm{b}}$ & $87.28^{\mathrm{f}} 85.07^{\mathrm{h}}$ & $266.56^{\mathrm{ab}} 181.69^{\mathrm{c}}$ \\
313 & PM & $142.8^{\mathrm{f}} 234.4^{\mathrm{d}}$ & $169.34^{\mathrm{a}} 140.99^{\mathrm{b}}$ & $85.19^{\mathrm{h}} 83.90^{\mathrm{hi}}$ & $268.85^{\mathrm{a}} 182.40^{\mathrm{c}}$ \\
318 & PM & $341.1^{\mathrm{b}} 576.5^{\mathrm{a}}$ & $169.30^{\mathrm{a}} 140.95^{\mathrm{b}}$ & $84.29^{\mathrm{h}} 82.90^{\mathrm{i}}$ & $264.50^{\mathrm{b}} 182.55^{\mathrm{c}}$ \\
323 & PM & $205.5^{\mathrm{e}} 304.3^{\mathrm{c}}$ & $126.02^{\mathrm{c}} 105.94^{\mathrm{d}}$ & $87.02^{\mathrm{fg}} 85.96^{\mathrm{gh}}$ & $120.74^{\mathrm{d}} 61.86^{\mathrm{h}}$ \\
328 & PM & $93.7^{\mathrm{h}} 144.0^{\mathrm{f}}$ & $125.97^{\mathrm{c}} 105.89^{\mathrm{d}}$ & $90.55^{\mathrm{cd}} 89.38^{\mathrm{de}}$ & $107.99^{\mathrm{e}} 50.34^{\mathrm{i}}$ \\
333 & PM & $42.8^{\mathrm{j}} 108.2^{\mathrm{g}}$ & $125.93^{\mathrm{c}} 105.85^{\mathrm{d}}$ & $94.14^{\mathrm{b}} 91.57^{\mathrm{c}}$ & $95.47^{\mathrm{f}} 42.88^{\mathrm{j}}$ \\
338 & PM & $20.3^{\mathrm{k}} 46.3^{\mathrm{i}}$ & $125.89^{\mathrm{c}} 105.82^{\mathrm{d}}$ & $97.69^{\mathrm{a}} 95.37^{\mathrm{b}}$ & $83.499^{\mathrm{a}} 30.92^{\mathrm{k}}$ \\
LSD $(P \leq 0.05)$ & & 8.855 & 3.326 & 1.663 & 3.326 \\
Significance & & HS & HS & HS & HS \\
\hline
\end{tabular}

$\Delta \mathrm{H}^{*}\left(\mathrm{~kJ} \mathrm{~mol}^{-1}\right)=\mathrm{E}_{\mathrm{a}}\left(129.7\right.$ and $118.1 \mathrm{~kJ} \mathrm{~mol}^{-1}$ for wild type organism and 100.6 and $85.6 \mathrm{~kJ} \mathrm{~mol}^{-1}$ for mutant M7) $-\mathrm{RT}$ where $\mathrm{E}_{\mathrm{a}}$ is activation energy, $\left.\left.\Delta \mathrm{G}^{*}\left(\mathrm{~kJ} \mathrm{~mol}^{-1}\right)=-\mathrm{RT} \ln \left(\mathrm{q}_{\mathrm{p}} \mathrm{h}\right) / \mathrm{k}_{\mathrm{B}} . \mathrm{T}\right)\right\}, \Delta \mathrm{S}^{*}\left(\mathrm{~kJ} \mathrm{~mol}^{-1} \mathrm{~K}^{-1}\right)$ is entropy of irreversible inactivation and was calculated from $\Delta \mathrm{S}^{*}=\left(\Delta \mathrm{H}^{*}-\right.$ $\left.\Delta \mathrm{G}^{*}\right) / \mathrm{T}$. 
glucosidase production. Further studies are needed to develop a continuous process for enzyme production that would fulfill this requirement of the process. A mutant strain of $H$. lanuginosa, producing $B$-xylosidase and other glycosidases (18) was also found to have improved BGL enzyme production. The possibility of using locally available substrates (Table 2) for enzyme production was promising in that induction on wheat straw and corncobs yielded BGL to a level greater than 2.95 and $3.17-$ fold of that induced by cellobiose. Corn steep liquor was essential for rapid uptake of substrates and microbial activity. The organism is prone to mutagenesis and will be more suitable for its application in futuristic bulk production of BGL for biofuels industry in Pakistan.

Thermodynamic studies provided sufficient insight into the cellular functions under varying conditions of fermentation temperature. They led to suggest that the phenomenon limiting BGL production metabolic network could be enzymatic reaction/ $\mathrm{s}$ under all varying fermentation conditions as observed for xylitol production (14). It was also concluded that the cell system of the mutant M7 exerted more protection against thermal inactivation, probably by acquiring chaperones or hyperglycosilation.

\section{ACKNOWLEDGEMENTS}

Pakistan Atomic Energy Commission, Islamabad and Pakistan Agricultural Research Council, Islamabad supported this work. Some chemicals were purchased from a USAID grant under PCST Proposal 6.163. This work formed a part of Ph.D. thesis work of Syed Ali Imran Bokhari who was financially supported by Higher Education Commission, Government of Pakistan through Indigenous $5000 \mathrm{PhD}$ Fellowship Programme. Technical assistance of Mr. Maqsood Ahmed and Miss Fatima Jalal is appreciated.

\section{RESUMO}

\section{Cinética de produção de ß-glucosidase por um mutante de Hemicola lanuginosa resistente a 2-deoxiglucose em fermentação submersa}

Um mutante de Hemicola lanuginosa resistente a 2deoxiglucose(M7) foi obtido através de exposição de conídios a raios $\gamma$, permitindo a expressão em caldo contendo $0,6 \%$ de 2deoxiglucose (DG) e celobiose (1\%) antes da semeadura em ágar DG esculina citrato de ferro amoniacal, da qual foram selecionadas as colônias com halo negro. Os parâmetros cinéticos para produção aumentada de B-glucosidase (BGL) foram obtidos empregando-se sabugo de milho como fonte de carbono. A combinação de espiga de milho com água de maceração de milho foi a que forneceu os valores mais altos nos parâmetros cinéticos de formação de todos os produtos. $\mathrm{O}$ efeito da temperatura na cinética e atributos termodinâmicos da produção de BGL pelas cepas selvagem e M7 foi avaliado empregando-se processo de batelada em oito temperaturas diferentes in frascos em agitação. O melhor desempenho foi observado a $45^{\circ} \mathrm{C}$ e $20 \mathrm{~g} . \mathrm{l}^{-1}$ de espiga de milho em $64 \mathrm{~h}$. Tanto a multiplicação quanto a formação do produto foram muito altas a $45^{\circ} \mathrm{C}$ e ambas estavam ligadas em condições ótimas de trabalho. O rendimento de BGL produzido pelo mutante M7 (1556 U.g ${ }^{-1}$ de espiga seca) foi significativamente superior aos valores reportados para todos os sistemas fúngicos e bacterianos. A mutação influenciou a termoestabilização no microrganismo, sendo que o mutante necessitou de energia de ativação mais baixa para multiplicação e valores mais baixos de entalpia e entropia para a formação do produto quando comparado à cepa selvagem e a outros microrganismos mesofilicos e termotolerantes. Na fase de inativação, os microrganismos necessitaram valores mais baixos de energia de ativação, entalpia e entropia para o equilíbrio da formação de produto, confirmando a natureza termofílica da máquina metabólica do mutante.

Palavras-chave: ß-glucosidase, entalpia, entropia, hemicelulose, cinética, regulação, fermentação submersa.

\section{REFERENCES}

1. Adams, M.; Kelly, R. (1998). Finding and using hyperthermophilic enzymes. Trends Biotechnol., 16, 329-332.

2. Aiba, S.; Humphrey, A.E.; Millis, N.F. (1973). Biochemical Engineering. $2^{\text {nd }}$ Edition, New York: Academic Press. pp. 92-127. ISBN: 0-12-045052-6.

3. Anand, L.; Vithayathil, P.J. (1996). Xylan-degrading enzymes from thermophilic fungus Humicola lanuginosa, action pattern of xylanase and B-gluosidase on xylans, xylooligomers and arabinooligomers. J. Ferment. Bioeng., 81, 511-517.

4. Antier, P.; Minjares, A.; Raimbault, M.; Viniegra, G. (1993). Pectinasehyperproducing mutants of Aspergillus niger C28B25 for solid state fermentation of coffee pulp. Enzyme Microb. Technol., 15, 254260.

5. Anwar, M.N.; Suto, M.; Tomida, F. (1996). Isolation of mutants of Penicillium purpurogenum resistant to catabolite repression. Appl. Microbiol. Biotechnol., 45, 684-687.

6. Aro, N.; Ilmen, M.; Salocheimo, A.; Pentilla, M. (2003). Acel of Trichoderma reese $i$ is a repressor of cellulase and xylanase expression. Appl. Environ. Microbiol., 69, 56-65.

7. Aro, N.; Salocheimo, A.; Ilmen, M.; Pentilla, M. (2001). ACEII, a novel transcriptional activator involved in regulation of cellulase and xylanase genes of Trichoderma reesei. J. Biol. Chem., 276, 24309-24314.

8. Badhan, A.K.; Chadha, B.S.; Kaur, J.; Saini, H.S.; Bhat, M.K. (2007). Production of multiple xylanolytic and cellulolytic enzymes by thermophilic fungus Myceliophthora sp IMI 387099. Biores. Technol., 98, 504-510.

9. Bhatia, Y.; Mishra, S.; Bisaria, V.S. (2002). Microbial B-glucosidase: cloning, properties and applications. Crit. Rev. Biotechnol., 22, 375407.

10. Bohm, A.; Boos, W. (2004). Gene regulation in prokaryotes by sub cellular relocalization of transcription factors. Curr. Opin. Microbiol., 7, 151-156. 
11. Bradford, M.M. (1976). A rapid and sensitive method for quantification of microgram quantities of proteins utilizing the principles of protein dye binding. Anal. Biochem., 72, 248-254.

12. Chand, P.; Aruna, A.; Maqsood, A.M.; Rao, L.V. (2005). Novel mutation method for increased cellulase production. J. Appl. Microbiol., 98, 318-323.

13. Chen, H.; Bakir, U.; Reilly, P.J.; Ford, C. (1994). Increased thermostability of Asn 182Ala mutant Aspergillus awamori glucoamylase. Biotechnol. Bioeng., 43, 101-105.

14. Converti, A.; Domingue, J.M. (2001). Influence of temperature and $\mathrm{pH}$ on xylitol production from xylose by Debarryomyces hansenii. Biotechnol. Bioeng., 75, 39-45.

15. Damaso, M.C.T.; Andrade, C.M.M.C.; Pereira Jr., N. (2002). Production and properties of the cellulose-free xylanase from Thermomyces lanuginosus IOC-4145. Braz. J. Microbiol., 33, 333-338.

16. Daniel, R.M. (1996). The upper limits of enzyme thermal stability. Enzyme Microb. Technol., 19, 74-79.

17. Daroit, D.D.J.; Silveira, S.T.; Hertz, P.F.; Bradelli, A. (2007). Production of extracellular B-glucosidase by Monascus purpureus on different growth substrates. Process Biochem. 42, 904-908.

18. Da Silava, R.; Yin, D.K.; Park, K.K. (1994). Application of thermostable xylanases from Humicola sp. for pulp improvement. J. Ferment. Bioeng., 77, 109-111.

19. De Groot, M.J.; van de Vondervoort, P.J.; de Vries, R.P.; van Kuyk, P.A.; Ruijter, G.J.; Visser, J. (2003). Isolation and characterization of two specific regulatory Aspergillus niger mutants shows antagonistic regulation of arabinan and xylan metabolism. Microbiology, 149, 1183-1191.

20. De Vries, R.P.; Visser, J.; de Graaff, L.H. (1999). CreA modulates the XlnR-induced expression on xylose of Aspergillus niger genes involved in xylan degradation. Res. Microbiol., 150, 281-285.

21. Dhillon, A.J.; Zorgi, C.; Camasasola, M.; Henriques, J.A.P. (2006). Use of 2-deoxyglucose in liquid media for the selection of mutant strains of Penicillium echninulatum producing increased cellulase and B-glucosidase activities. Appl. Microbiol. Biotechnol., 70, 740-746.

22. Duenas, R.; Tengerdy, R.P.; Gutierrez-Correa, M. (1995). Cellulase production by mixed fungi in solid-substrate fermentation of bagasse. World J. Microbiol. Biotechnol., 11, 333-337.

23. Filho Ex, F. (1996). Purification and characterization of a Bglucosidase from solid-state cultures of Humicola grisea var. thermoidea. Can. J. Microbiol., 42, 1-5.

24. Furlan, A.S.; Schneider, A.S.L.; Merckle, R.; Carvalho-Johans, M.F.; Jonas, R. (2000). Formulation of lactose-free, low-cost culture medium for the production of $\beta$-galactosidase by Kluyveromyces marxianus. Biotechnol. Lett., 22, 1195-1198.

25. Gomes, I.; Gomes, J.; Gomes, D.J.; Steiner, W. (2000). Simultaneous production of high activities of thermostable endo-glucanase and $\mathrm{B}$ glucosidase by the wild thermophilic fungus Thermoascus aurantiacus. Appl. Microbiol. Biotechnol., 53, 461-468.

26. Hrmova, M.; Petrakova, E.; Biely, P. (1991). Induction of cellulose and xylan-degrading enzyme systems in Aspergillus terreus by homo and hetero-disaccharides composed of glucose and xylose. J. Gen. Microbiol., 137, 541-547.

27. Kuhad, R.C.; Kapoor, M.; Rustagi, R. (2004). Enhanced production of an alkaline pectinase from Streptomyces sp. RCK-SC by wholecell immobilization and solid-state cultivation. World J. Microbiol. Biotechnol., 20, 35-37.

28. Kvesitadze, G.I.; Svanbidez, R.S.; Tsuprun, V.L.; Nizharadze, D.N.; Buachidze, T.S. H. (1990). Quaternary structure and properties of enzyme $B$-glucosidase isolated from a thermophilic culture of Aspergillus wentii. Bioor. Khim., 16, 881-888.
29. La Grange, D.C.; Pretoriusm, I.S.; Claeyssens, M.; van Zyl, W.H. (2001). Degradation of xylan to D-xylose by recombinant Saccharomyces cerevisiae co expressing the Aspergillus niger betaxylosidase $(x \ln \mathrm{D})$ and the Trichnoderma reesei xylanase ii $(x y n 2)$ genes. Appl. Environ. Microbiol., 67, 5512- 5519.

30. Latif, F.; Puls, J.; Malik, K.A. (1988). Effect of alkali pretreatment on the enzymatic hydrolysis of plants grown in saline lands. Biomass, $17,105-114$.

31. Lin, J.; Pillay, B.; Singh, S. (1999). Purification and biochemical characteristics of $B$-D-glucosidase from a thermophilic fungus, Thermomyces lanuginosus-SSBP. Biotechnol. Appl. Biochem., 30, 81-87.

32. Lynd, L.R.; Weimer, P.J.; van Zyl, W.H.; Pretorius, I.S. (2000) Microbial cellulose utilization: fundamentals and biotechnology. Microbiol. Mol. Biol. Rev., 66, 506-577.

33. Maicas, S.; Mateo, J.J. (2005). Hydrolysis of terpenyl glycosides in grape juice and other fruit juices: a review. Appl. Microbiol. Biotechnol., 67, 322-335.

34. Miller, G.L. (1959). Use of dinitrosalisylic acid (DNS) for determination of reducing sugars. Anal. Chem. 31, 426-428.

35. Phisalaphong, N.; Srirattana, N.; Tanthapanichakoon, W. (2006). Mathematical modeling to investigate temperature effect on kinetic parameters of ethanol fermentation. Biochem. Eng. J., 28, 36-43.

36. Phutela, U.; Dhuna, V.; Sandhu, S.; Chadha, B.S. (2005). Pectinase and polygalacturonase production by a thermophilic Aspergillus fumigatus isolated from decomposting orange peels. Braz. J. Microbiol., 36, 63-69.

37. Rajoka, M.I.; Bashir, A.; Hussain, M.R.A.; Malik, K.A. (1998), Mutagenesis of Cellulomonas biazotea for improved production of cellulases. Folia Microbiol., 43, 15-22.

38. Rajoka, M.I.; Bashir, A.; Hussain, M.R.A.; Parvez, S.; Ghauri, T.M.; Malik, K.A. (1998). Cloning and expression of B-glucosidase genes in Escherichia coli and Saccharomyces cerevisiae using shuttle vector pYES2.0. Folia Microbiol., 43, 129-135.

39. Rajoka, M.I.; Bashir, A.; Malik, K.A. (1997). Mutagenesis of Cellulomonas biazotea for enhanced production of xylanases. Biores. Technol., 62, 99-108

40. Rajoka, M.I.; Latif, F.; Khan, S.; Shahid, R. (2004). Kinetics of improved productivity of $B$-galactosidase by a cycloheximideresistant mutant of Kluyveromyces marxianus. Biotechnol. Lett., 26, 741-74.

41. Rosgaard, L.; Pedersen, S.; Cherry, J.R.; Harris, P.; Meyer, A.S. (2006) Efficiency of new fungal cellulase systems in boosting enzymatic degradation of barley straw lignocellulose. Biotechnol. Prog., 22, 493-498.

42. Singh, S.; Madlala, A.M.; Prior, B.A. (2003). Thermomyces lanuginosus; properties of strains and their hemicellulases. FEMS Microbiol. Rev., 27, 3-16.

43. Sanchez, S.; Bravo, V.; Moya, A.J.; Castro, E.; Camacho. F. (2004). Influence of temperature on the fermentation of D-xylose by Pachysolen tannophilus to produce ethanol and xylitol. Process Biochem., 39, 673-679.

44. Sun, Y.; Cheng. J. (2002). Hydrolysis of lignocellulosic materials for ethanol production: a review. Biores. Technol., 83, 1-11.

45. Thygesen, A.; Thomsen, A.B.; Schmidt, A.S.; Jorgensen, H.; Ahring, B.K.M.; Olsson. L. (2003). Production of cellulose and hemicellulosedegrading enzymes by filamentous fungi cultivated on wet oxidized wheat straw. Enzyme Microb. Technol., 32, 606-615.

46. Vieille, C.; Zeikus, J.G. (1996). Thermozymes: identifying molecular determinants of protein structural and functional stability. Trends Biotechnol., 14, 183-190. 